DOI https://doi.org/10.30525/978-9934-26-184-8-7

\title{
БІОХІМІЧНИЙ СКЛАД ТА ТЕХНОЛОГІЧНА ОЦІНКА ЗЕРНА ІНТРОГРЕСИВНИХ ЛІНІЙ ПШЕНИЦІ М'ЯКОЇ ОЗИМОЇ 3 ГЕНАМИ ВИСОКОЇ БІЛКОВОСТІ ВІД TRITICUM DICOCCOIDES TA AEGILOPS TAUSCHII
}

\author{
Фанін Я. С. \\ аспірант, молодший науковий співробітник \\ Селекиійно-генетичний інститут
}

Національного чентту насіннєзнавства та сортовивчення

\section{Литвиненко М. А.}

доктор сільськогосподарських наук, професор, академік Національної академії аграрних наук України, завідувач відділу селекиії та насінництва пшениці

Селекиійно-генетичний інститут

Національного центру насіннєзнавства та сортовивчення

\section{Молодченкова О. О.}

доктор біологічних наук, старший науковий співробітник, завідувач лабораторії

Селекиійно-генетичний інститут

Національного иеенту насіннєзнавства та сортовивчення м. Одеса, Украӥна

Традиційно пріоритетним напрямом роботи Селекційногенетичного інституту-Національного центру насіннєзнавства та сортовивчення (СГІ-НЦНС) є створення сортів пшениці м'якої озимої (Triticum aestivum L.) з генетично обумовленим високим рівнем хлібопекарської якості зерна, потенціал якого повною мірою реалізується тільки за умови вмісту білка у борошні не нижче 12,5 \% [1] Проте в останні десятиріччя, на противагу зростанню врожайності, якість зерна погіршується, включаючи показник вмісту білка [2]. Ця проблема може бути вирішена завдяки залученню нового генетичного матеріалу, наприклад, 
джерел цінних ознак, створених в результаті віддаленої гібридизації, та точному встановленню зв'язку між вмістом білка 3 іншими показниками якості, а також селективними ознаками [3]. В даному випадку можна розглянути декілька джерел генів підвищеної білковості. Відомо, що геном D позитивно впливає на характеристики, пов'язані з продуктивністю та якістю зерна хлібопекарського типу [4] Тим не менш, ряд авторів стверджують, що пряма гібридизація для покращення пшениці не отримала належної уваги через вкрай низьку схрещуваність T. aestivum 3 Ae. tauschii [5]. Про можливість передачі генів підвищеного вмісту білка не тільки від $T$. dicoccoides, а й від інших зразків дикої двозернянки повідомлялося у роботах. Інтрогресія функціональних алелів $G p c-B 1$ - цінний ресурс для поліпшення вмісту білка у зерні. Однією із особливостей цього локусу є те, що він пов'язаний 3 фізіологічним старіння листя. Це зумовлює перенесення поживних речовин у зернівку, підвищуючи у такий спосіб вміст важливих макро- та мікроелементів [7]. За літературними даними, існує думка, що введення функціональних алелів $G p c-B 1$ у нові сорти може бути механізмом для часткового ослаблення існуючої негативної кореляції між врожайністю та вмістом білка [6]. Підтримувати та зберігати в нормі виявлений ген (алель) у пшенично-чужорідних гібридів (ПГГ) набагато простіше, ніж відстежувати їх у популяціях диких родичів [8].

Метою нашої роботи було вивчити біохімічний склад та дати технологічну оцінку зерна інтрогресивних ліній пшениці м'якої озимої з генами підвищеної білковості від $T$. dicoccoides та Ae. tauschii, дослідити взаємодії чужорідних генів високої білковості від T. dicoccoides та Ae. tauschii $з$ генотипами комерційних сортів СГІ-НЦНС, які добре себе зарекомендували на території України за показниками адаптивності та стійкості до біотичних i абіотичних факторів.

Об’єктом досліджень були нові інтрогресивні лінії пшениці м'якої озимої, створені методом віддаленої гібридизації у відділі загальної та молекулярної генетики та відділі генетичних основ селекції СГІ-НЦНС. Матеріалом для вивчення гена GPC-B1 слугували лінії $\mathrm{F}_{6}-\mathrm{F}_{7}$, отримані від схрещування сорту Куяльник (Triticum aestivum L.) з лінією-донором гена Gpc-B1 від T. turgidum 28 
ssp. Dicoccoides, які були надані д.б.н. О.І. Рибалка. Матеріалом для вивчення впливу генів високої білковості від A. tauschii були лінії, отримані в результаті 3-10 насичених схрещувань адаптивних сортів пшениці Одеська 267, Куяльник, Зміна, Ватажок, Віген, Альбатрос з оригінальними первинними ознаковими лініями, а також колекційними зразками, штучними видами пшениці та амфіплоїдами, схрещування сорту Селянка з мексиканськими елітними синтетиками (амфіплоїдами T. durum Desf./Aegilops tauschii Coss.), наступних ступінчастих схрещувань отриманих гібридів із сучасними сортами та 4-6 самозапилень, які були надані к.б.н. I. I. Моцним.

Польові дослідження проводилися по чорному пару на дослідній ділянці відділу селекції та насінництва пшениці СГІ-НЦНС у період 2019-2021 рр. Дослід закладався в 3-х кратній повторності 3 розміром дослідної ділянки $5 \mathrm{~m}^{2} 3$ використанням широкорядного способу сівби (ширина міжрядь 30 см) на двох агрофонах з додаванням аміачної селітри в нормі 60 і 120 кг/га діючої речовини. В якості сортів стандартів використовувались найбільш адаптивні та розповсюджені сорти - Безоста1, Одеська 51, Куяльник, Антонівка.

Загальний вміст білка визначали методом К'єльдаля на приладі Kjeltec-Auto 1030 та методом інфрачервоної спектрометрії (NIR) [9]. Рівень седиментації визначали методом седиментації SDS30'К, розробленим у відділі генетичних основ селекції СГІ - НЦНС [10].

В результаті вивчення інтрогресивних ліній пшениці за обидва роки досліджень було встановлено, що вміст білка в період вегетації 2019-2020 pp. на агрофоні N60 варіював серед сортівстандартів від 11,9 \% (сорт Куяльник) до 15 \% (сорт Одеська 51); серед ліній з геном $G P C-B 1$ - від 13,6\% до 15,8 \%. Показано, що в 2020-2021pp. білковість сортів-стандартів була дещо нижчою від 10, 9\% (сорт Антонівка) до 13\% (сорт Безоста 1), а у ліній 3 геном GPC-B1 - 11,7-14,1\%. Така ж тенденція спостерігалась на агрофоні N120 - 14,9\% (сорт Антонівка) і 17\% (сорт Одеська 51), у ліній з геном $G P C-B 1-12,9-15,7 \%$. Це може бути нетипова реакція рослин досліджених генотипів на зміну опадів в рік, коли сума опадів в період вегетації нижча, а рівень білка вище, i 
навпаки - при збільшені опадів зменшувався вміст загального білка. Реакція загального вмісту білка на збільшення агрофону у лінії з геном $G P C$-B1 складала $+20-25 \%$, у лініях з генами високої білковості від Ae. tauschii приріст вмісту білка лише у деяких випадках складав $20 \%$, у більшості випадків він був менше $10 \%$, у сортів -стандартів від 15-20\%.

За результатами аналізу досліджених генотипів методом седиментації SDS30'K 0, який має високу кореляційну залежність саме 3 якістю білка i може слугувати надійним критерієм прогнозування рівня фактичної хлібопекарської якості зразка пшениці, всі лінії з геном $G p c-B 1$ мали показник седиментації не менше ніж 80 мл. на двох агрофонах, що приблизно на 20 мл. більше, ніж у сортів-стандартів.

Таким чином, отримані результати дослідження впливу гена $G p c-B 1$ і генів високої білковості від Ae. tauschii на вміст білка та деякі технологічні характеристики зерна вивчених інтрогресивних ліній пшениці в порівнянні зі сортами-стандартами, можна розглядати як попередні, оскільки цей матеріал ще потребує ретельної селекційної проробки та більшого вивчення по роках $\mathrm{i}$ в різних кліматичних зонах. Але вже попередні дані підтверджують нашу думку, що ген $G p c-B 1$ та гени підвищеної білковості від Ae. tauschii та T.dicoccoides впливають на рівень білка та деякі технологічні характеристики зерна пшениці. Так, інтрогресивні лінії від T.dicoccoides i Ae. tauschii, порівняно 3 сортамистандартами, містили в середньому вміст білка в зерні на 1,5-2 \% більше, рівень седиментації перевищував сорти-стандарти на 1520 мл. Оскільки вміст білка в зерні є однією з головних ознак для пшениці, з урахуванням успішного світового досвіду використання генів інтрогресивних ліній від T.dicoccoides і A. tauschii, ми вважаємо, що ці гени, як цільові, мають бути в усіх селекційних програмах на підвищення біологічної цінності сортів пшениці.

\section{Література:}

1. Литвиненко М.А., Голуб Є.А., Хоменко Т.М. Особливості створення та ідентифікації екстрасильних за хлібопекарськими властивостями сортів пшениці м'якої озимої (Triticum 
aestivum L.). Plant Varieties Studying and Protection. 2018. T. 14, № 1. C. 66-74. doi: 10.21498/2518-1017.14.1.2018.126511.

2. Полянецька І. О. Вміст білка та його вихід з урожаєм зерна пшениці озимої залежно від сорту / І. О. Полянецька, В. В. Любич, О. Г. Сухомуд. Наукові праиі інституту біоенергетичних культур і иукрових буряків. - 2014. Випуск 21. С. 235-239.

3. Рибалка О.І. Якість пшениці та її поліпшення. К.: Логос, 2011.495 c.

4. Cox T.S., Wu J., Wang S., Cai J., Zhong Q., Fu B. Comparing two approaches for introgression of germplasm from Aegilops tauschi into common wheat. Crop J. 2017;5:355-362. DOI 10.1016/j.cj. 2017. 05.006

5. Ogbonnaya F.C., Abdalla O., Mujeeb-Kazi A., Kazi A.G., Xu S.S., Gosman N., Lagudah E.S., Bonnett D., Sorrells M.E., Tsujimoto H. Synthetic hexaploids: harnessing species of the primary gene pool for wheat improvement. Plant Breed. Rev. 2013;37:35-122. DOI 10.1002/9781118497869.ch2.

6. Похилько С. Ю. Дослідження генотипів пшениці м'якої 3 перенесеним геном Gpc-B1 від Triticum turgidum ssp. dicoccoides / С. Ю. Похилько, А. В. Трояновська, А. І. Степаненко, Б. В. Моргун. Фактори експериментальної еволюиї організмів. 2016. T. 18. C. 132-135.

7. Uauy $\mathrm{C}$. The high grain protein content gene $\mathrm{Gpc}-\mathrm{B} 1$ accelerates senescence and has pleiotropic effects on protein content in wheat / Uauy C., Brevis J. C., Dubcovsky J. // J. Exp. Bot. 2006. V. 57. P. 2785-2794.

8. Абугалиева А.И., Савин Т.В. Биохимический состав и технологическая оценка зерна интрогрессивных форм озимой мягкой пшеницы с участием различных видов Triticum и Aegilops. Вавиловский журнал генетики и селекции. 2018;22(3):353-362. DOI 10.18699/VJ18.371

9. ГОСТ 10846-91 Зерно и продукты его переработки. Метод определения белка. Межгосударственный стандарт. 2009. С. 8.

10. Пат. № 17023 Україна, (2006) А01Н 1/04. Спосіб непрямої оцінки «сили» борошна - седиментація SDS-30 [Текст] / О.І. Рибалка, М.В. Червоніс, М.Г. Парфентьєв, Д.В. Аксельруд; патентообладатель Селекційно-генетичний інститут.

№u200610062; заявл. 06.02.2006; опубл. 15.09.2006; Бюл. № 9. -6 с. 